RFP-1842

October 2, 1972

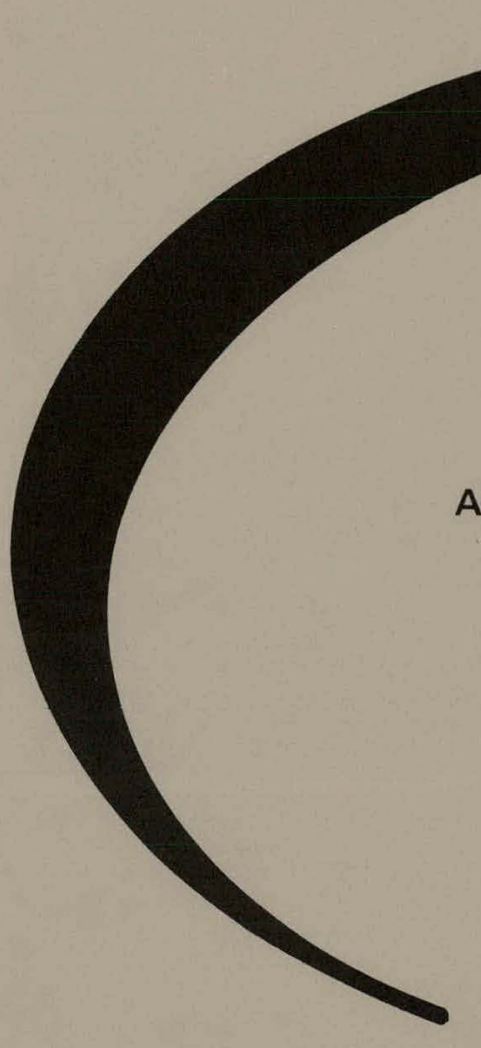

\title{
AN IMPROVED TECHNIQUE FOR PRODUCING HIGH SURFACE FINISH BERYLLIUM FOIL
}

John G. Avery

James F. Norris
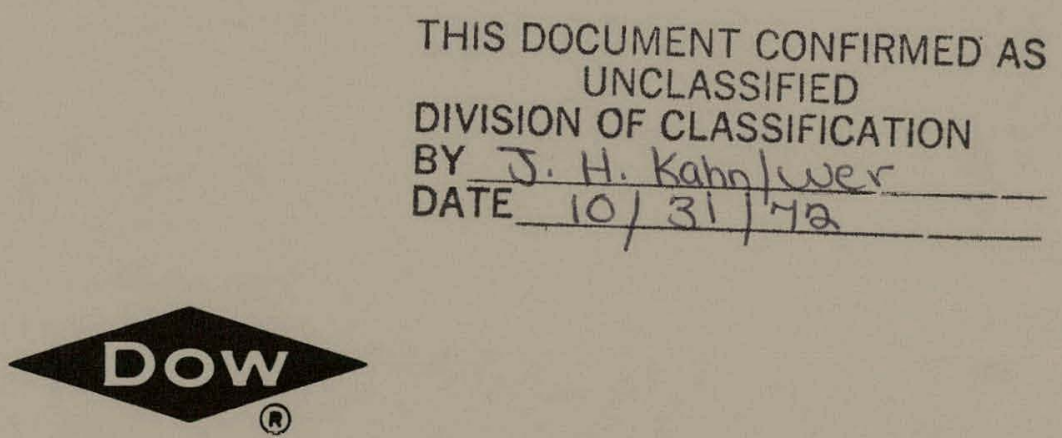

DOW CHEMICAL U.S.A. ROCKY FLATS DIVISION

P. O. BOX 888

GOLDEN, COLORADO 80401

U.S. ATOMIC ENERGY COMMISSION CONTRACT AT(29-1)-1106 


\section{DISCLAIMER}

This report was prepared as an account of work sponsored by an agency of the United States Government. Neither the United States Government nor any agency Thereof, nor any of their employees, makes any warranty, express or implied, or assumes any legal liability or responsibility for the accuracy, completeness, or usefulness of any information, apparatus, product, or process disclosed, or represents that its use would not infringe privately owned rights. Reference herein to any specific commercial product, process, or service by trade name, trademark, manufacturer, or otherwise does not necessarily constitute or imply its endorsement, recommendation, or favoring by the United States Government or any agency thereof. The views and opinions of authors expressed herein do not necessarily state or reflect those of the United States Government or any agency thereof. 


\section{DISCLAIMER}

Portions of this document may be illegible in electronic image products. Images are produced from the best available original document. 


\section{LEGAL NOTICE}

This report was prepared as an account of wutk sponsored by the United States Government. Neither the United States nor the United States Atomic Eneryy Commission, nor any of their employees, nor any of their contractors, subcontractors, or their employees, makes any warranty, expressed or implied, or assumes any legal liability or responsibility for the accuracy, completeness or usefulness of any information, apparatus, product or process disclosed, or represents that its use would not infringe privately owned rights.

Printed in the United States of America

Available from the

National Technical Information Service

U. S. Department of Commerce

Springfield, Virginia 22151

Price: Printed Copy $\$ 3.00$; Microfiche $\$ 0.95$ 
Printed

October 2, 1972
RFP-1842

UC-25 METALS, CERAMICS, AND MATERIALS

TIC-4500 - 56th Ed.

\section{AN IMPROVED TECHNIQUE FOR PRODUCING \\ HIGH SURFACE FINISH BERYLLIUM FOIL}

John G. Avery

James F. Norris.

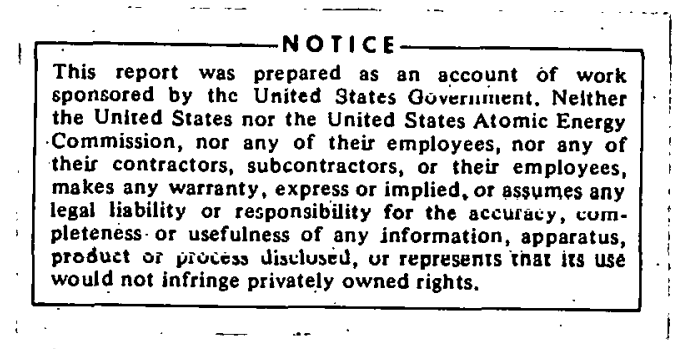

DOW CHEMICAL U.S.A.

ROCKY FLATS OIVISION

P..O. BOX 888

GOLDEN, COLORADO 80401

Prepared under Contract AT(29-1)-1106

$$
\text { for the }
$$

Albuquerque Operations Office

U. S. Atomic Energy Commission

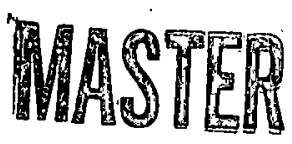


RFP-1842 


\section{CONTENTS}

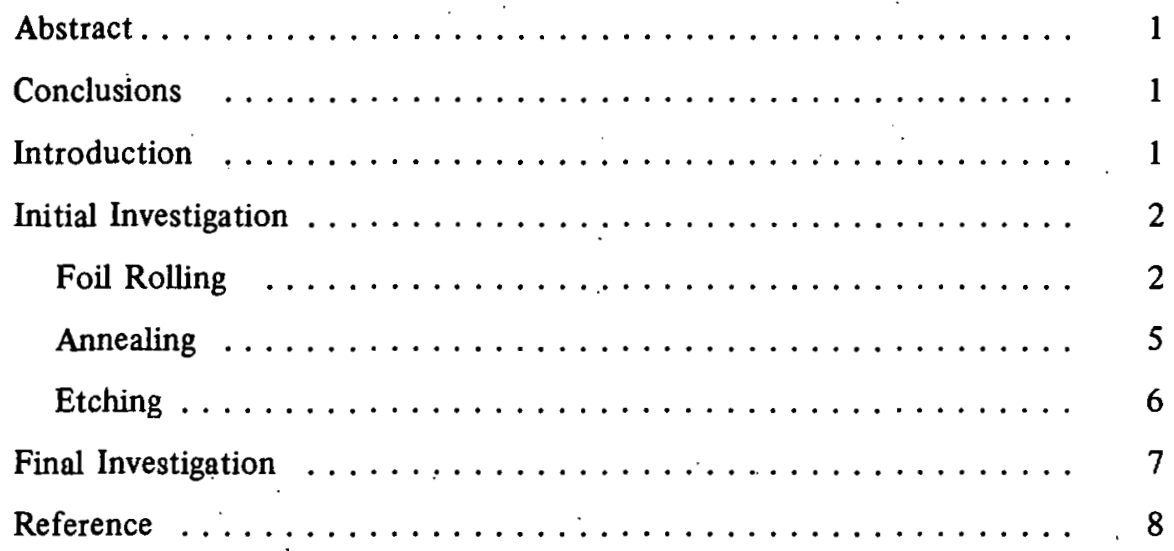




\section{ACKNOWLEDGMENTS}

The authors thank Mr. Willard Leverett for his helpful suggestions and information on prcvious foil improvement programs, and Mr. Arvel Brewer for

electron microscopy studies of foil rolled by the various rolling schedules in this program. 


\title{
AN IMPROVED TECHNIQUE FOR PRODUCING HIGH SURFACE FINISH BERYLLIUM FOIL
}

\author{
John G. Avery and James F. Norris
}

\begin{abstract}
A method of producing beryllium foil with a better surface finish than present foil, and at a lower cost than the present method, has been conceptually developed. This method is performed with the rolls and the beryllium at $800^{\circ} \mathrm{F}$, which is just below the temperature at which significant oxidation of beryllium begins. Subsequent annealing at $1200^{\circ} \mathrm{F}$ in a $10^{-6}$ torr vacuum produces a ductile foil whose surface does not require etching to remove oxide.
\end{abstract}

\section{CONCLUSIONS}

Based on the initial and final experimental work the following conclusions can be drawn.

- High quality surface finish beryllium foil can probably be produced on a four-high mill utilizing high hardnesshigh surface finish rolls which are heated to $800^{\circ} \mathrm{F}$. High purity foil heated to $800^{\circ} \mathrm{F}$ would be rolled through the heated rolls inducing at least $50 \%$ total reduction. Annealing would be done at $1200^{\circ} \mathrm{F}$ for 3 hours at $10^{-6}$ torr level of vacuum.

- The above procedure is a reasonable extrapolation of experimental results; however, equipment does not exist at Rocky Flats to provide foil in this manner on a cast sales or production basis.

- If maximum ductility foil is desired, an anneal at a higher temperature than $1200^{\circ} \mathrm{F}$ is rcquired, and subsequent etching is necessary to remove oxide.

In this method a cost savings of over $50 \%$ in process and labor costs can be realized as compared with the present cold roll method. This savings is possible because over half of the roll-anneal-etch stages in the conventional cold roll schedule (see Appendix I) can be eliminated by using heated rolls.

\section{INTRODUCTION}

Beryllium foil must be ductile and have uniform thickness so it can be fabricated into desired shapes. A high level of surface finish is also a desirable feature.

The present method of producing beryllium foil is long and tedious. The procedure (see Appendix I) involves a number of stages in the three step rolling, annealing, and etching procedure which is required to produce a thin beryllium foil.

The present method of producing beryllium foil results in a low level of surface finish. After a particular amount of rolling, the foil is annealed to induce softness before rolling continues. An oxide layer is formed during this annealing. If the oxide layer is not removed before rolling is resumed, the oxide breaks up and, being harder then the beryllium, it becomes impregnated in the surface and causes a poor surface finish. To avoid this situation, the oxide is removed by a chemical etch after each annealing. This etching leaves an oxide free surface, but the as-rolled surface roughness increases from $15 \mathrm{rms}$ to between 30 and $70 \mathrm{rms}$, depending on the etch used.

Another problem is the amount of labor involved in the present process. In addition to the time involved, as much as $20 \%$ of the foil is lost in each step of processing because of trimming of cracked portions of the foil. Therefore, from an economic standpoint it would be desirable to decrease the number of operations involved in producing the finished product.

Other metal foils are produced by rolling at low tempera. ture so that oxidation is not a problem. High surface finish rolls produce a correspondingly high level of surface finish on the foil (usually less than $10 \mathrm{rms}$ ). The foil is then annealed in a protective atmosphere, or vacuum, at a temperature low enough to prevent oxide formation but adequate to provide a sufficient level of ductility in the finished foil.

The object of this investigation was to determine if a procedure similar to that used on more ductile metal toils could be developed for beryllium and produce a higher surface finish foil; preferably, at a lower cost than the present method. The improvements described are the results of several attempts at success in three areas of foil technology, namely; rolling, annealing, and etching. The initial work, which defined the basic limitations in the methods used to improve the foil production process, is described in the Initial Investigation section. The results of this initial investigation led to the technique described in the experimental procedure section. 


\section{INITIAL INVESTIGATION}

Beryllium foil used in this investigation was produced by induction melting SR* grade flake into a billet 2 in. by 2 in. by 4 -in. high. High purity foil is better from a fabrication standpoint, as it does not oxidize as severely during annealing as foil made from normal Rocky Flats purity level heryllium. High purity foil also produces better x-ray windows as it has a more uniform $\mathrm{Z}$ cross section. The billet was sectioned horizontally into sections, each 2 in. by 2 in. by 1 -in. high. These were canned in stainless steel, the cans were electron beam welded, and rolled. After the beryllium was reduced from 1 in. to 0.080 in., the cans were removed and the beryllium sheet was reduced by bare rolling to n.012-in. thickness. It was then annealed at $760^{\circ} \mathrm{C}$ and etched in a solution consisting of $48 \mathrm{vol} \%$ $\mathrm{HNO}_{3}-4$ vol\% $\mathrm{HF}-48$ vol\% $\mathrm{H}_{2} \mathrm{O}$ to remove the surface oxide. The final sheet was 0.010 -in. thick and had a surface finish of 70 to $90 \mathrm{in} / \mathrm{in}$ rms. The chemical composition of the billet is shown in Table 1 .

Table 1. Chemical Composition of Induction Melted and Cast Ingots Made from SR Grade Flake.

\begin{tabular}{crcr} 
Element & PPM & Element & PPM \\
\cline { 1 - 1 } & 13 & $\mathrm{Ti}$ & 1 \\
$\mathrm{O}$ & 50 & $\mathrm{Cr}$ & 10 \\
$\mathrm{Na}$ & 10 & $\mathrm{Mn}$ & 28 \\
$\mathrm{Mg}$ & 20 & $\mathrm{Fe}$ & 200 \\
$\mathrm{Al}$ & 10 & $\mathrm{Ni}$ & 10 \\
$\mathrm{Si}$ & 120 & $\mathrm{Ce}$ & 35 \\
$\mathrm{Cl}$ & 150 & $\mathrm{Ph}$ & 10 \\
$\mathrm{Ca}$ & 160 & $\mathrm{Ba}$ & 1 \\
\hline
\end{tabular}

\section{Foil Rolling}

Rolling was done to determine if beryllium sheet could be cold rolled in high surface finish rolls as described in the introduction. A S tanat 6-in. mill was used for all rolling. A four-high setup was used, with 0.820 -in.-diameter tungsten carbide work rolls and 6-in.-diameter backup rolls.** Roll speed was constant at $50 \mathrm{fpm}$ for all rolling. The malleability of the foil was determined in the following manner: The mill setting was reduced 0.001 in. per pass. The foil was unidirectionally rolled. The appearance of heavy edge cracking or cracking away from the edges of the foil was taken to be indicative that the maximum reduction the foil could tolerate has been reached. $f$ This

* $S R$ is an electroly tically refined beryllium with lower impurity levels than commercially pure grades.

* Erroneous malleability values will result if the ratio of roll diameter to initial foil thickness is allowed to vary.

† Slight edge cracks, as the result of edge defects, were not counted as indicative of the maximum ductility until the cracks propagated wcll into the width of the sample. maximum reduction will be referred to, in this report, as the total available ductility in the foil.

Room temperature (RT) rolling (that is, foil and rolls at RT) resulted in a total available ductility in the foil of $7 \%$. This amount of reduction was insufficient to produce a $15 \mathrm{in} /$ in surface finish, although it did improve the surface finish from $70 \mu \mathrm{in} / \mathrm{in}$ to $40 \mu \mathrm{in} / \mathrm{in}$.

To increase the total available ductility the foil was heated before rolling. The available ductilities were determined for foil heated to $200,400,600,800$, and $1000^{\circ} \mathrm{F}$, rolling through RT cold rolls. The results are shown in Figure 1. The graph also shows that total available ductility increases up to a value of $72 \%$ at $800^{\circ} \mathrm{F}$. Ahove $800^{\circ} \mathrm{F}$ significant oxidation results and a grey surface laycr forms. Therefore, $800^{\circ} \mathrm{F}$ is the maximum temperature for rolling to a bright, oxide-free surface.

In addition to determining the total available ductility as a function of foil temperature, the surface finishes were determined as a function of total reduction and foil temperature.

Figure 2 shows the percentage of the total available ductility needed to produce a given surface finish of $15 \mathrm{rms}$ at various foil temperatures. As shown in Figure 2, at $200^{\circ} \mathrm{F}, 80 \%$ of the total available ductility is required to produce the same finish. The desirability of using only part of the available ductility to produce a quality foil hecame evident when various pieces of rolled foil were examined metallographically.

Referring to Figure 1, a number of combinations of foil temperature and reduction could be used to roll foil just short of the total available ductility point; $375^{\circ} \mathrm{F}$ and $13 \%$ were arbitrarily chosen.

Figures 3, 4, 5, and 6 show the stal ling sheet prior to room lemperature rolling. Therc is an equiaxed structure with no micorcracks.

This sheet was rolled $13 \%$ at $375^{\circ} \mathrm{F}$ which is just below the total ductility available ds shown in Figure 1. Figures 7, 8, 9 , and 10 show the as-rolled foil. The structural characteristics have been altered by the rolling operation. Low angle grain boundaries and microcracks are present. These microcracks are located in the interior of the foil. They will not weld or close during annealing and they are permanent and detrimental to the mechanical properties and uniformity of the foil. Further metallographic examination showed that, as the sheet was reduced, microcracking occurred slightly before macrocracking. Therefore, to produce internally sould foil it could only be reduced approximately $80 \%$ of the values given in Figure 1 . 


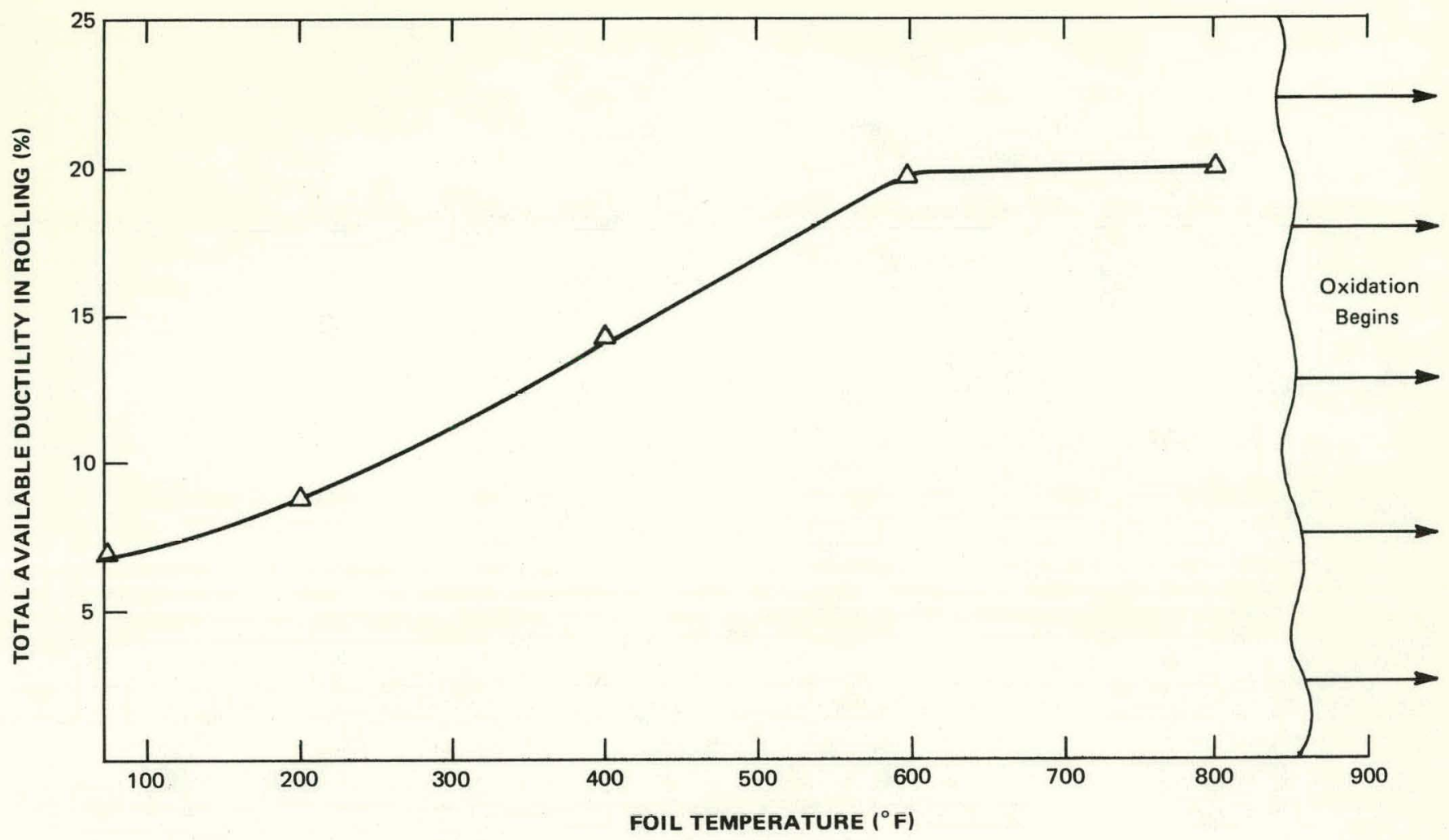

Figure 1. Total Available Ductility of 0.010-in. Beryllium Foil as a Function of Foil Temperature.

Figure 2. Percent of the Ductility-to-Fracture Needed to Obtain a 15 rms Finish as a Function of Foil Temperature.

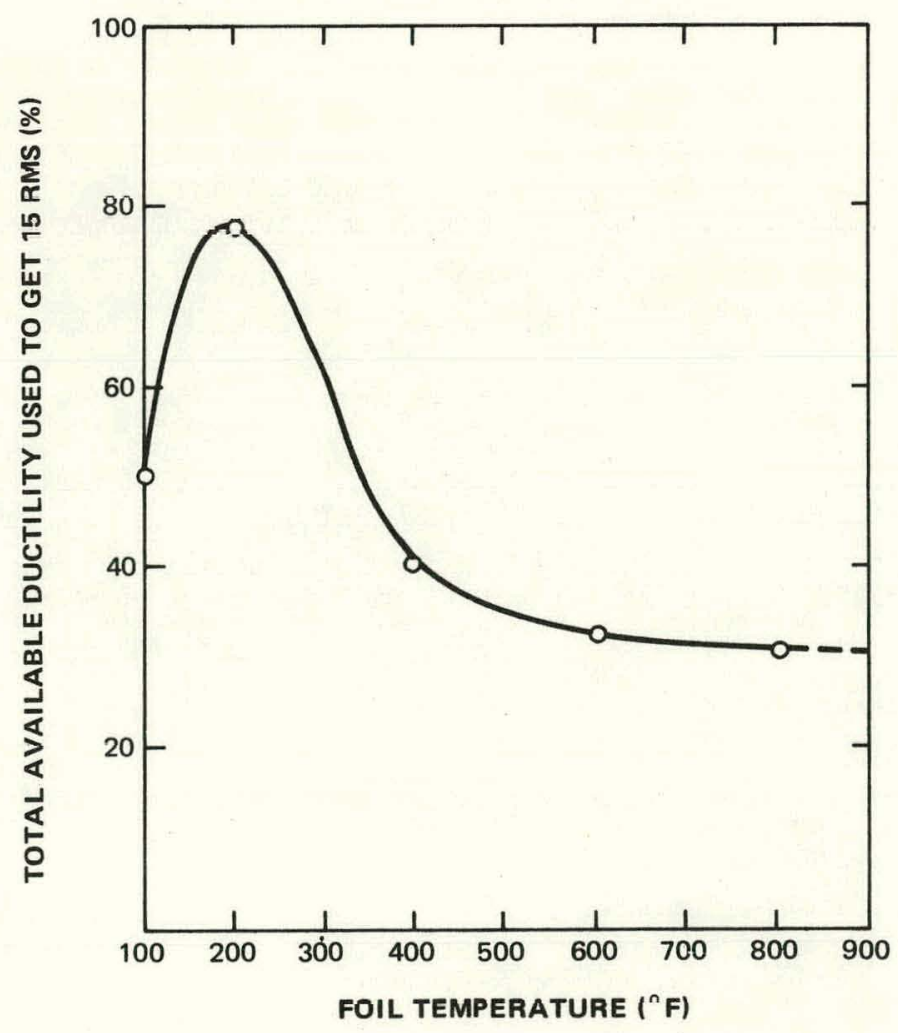

Figure 3. Starting Sheet for Beryllium Foil Rolling Experiments Showing No Microcracks. Transverse view 200X. Bright Field.

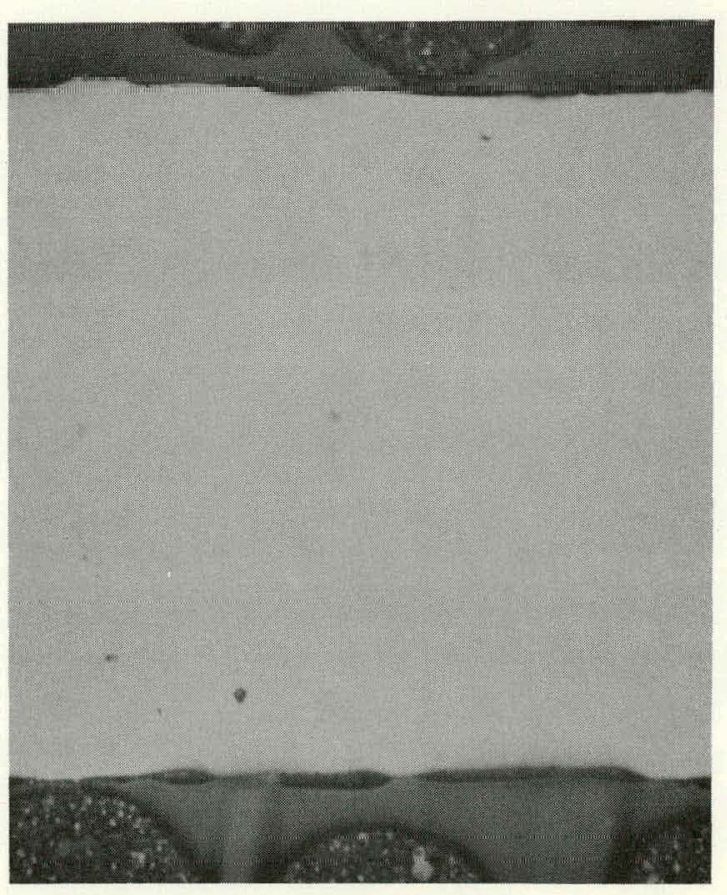




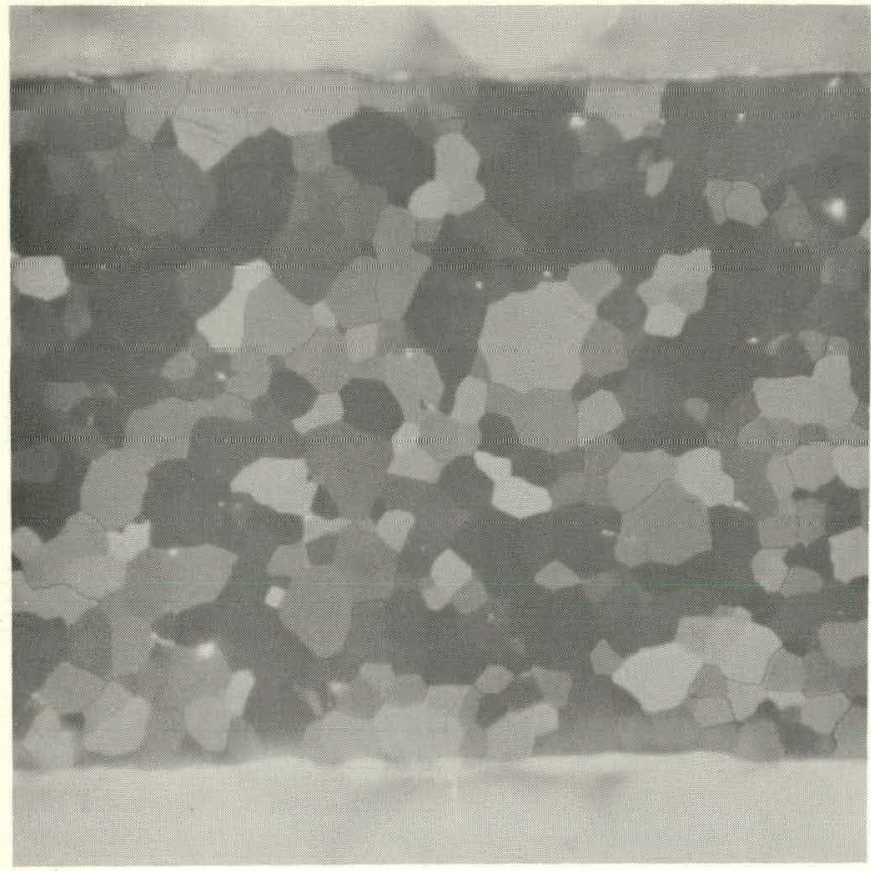

Figure 4. Starting Sheet for Beryllium Foil Rolling Experiments Showing Equiax Structure. Transverse view 200X. Polarized Light.

Figure 6. Same Material as Shown in Figures $\mathbf{3}$ and 4. Longitudinal view 200X. Polarized Light.

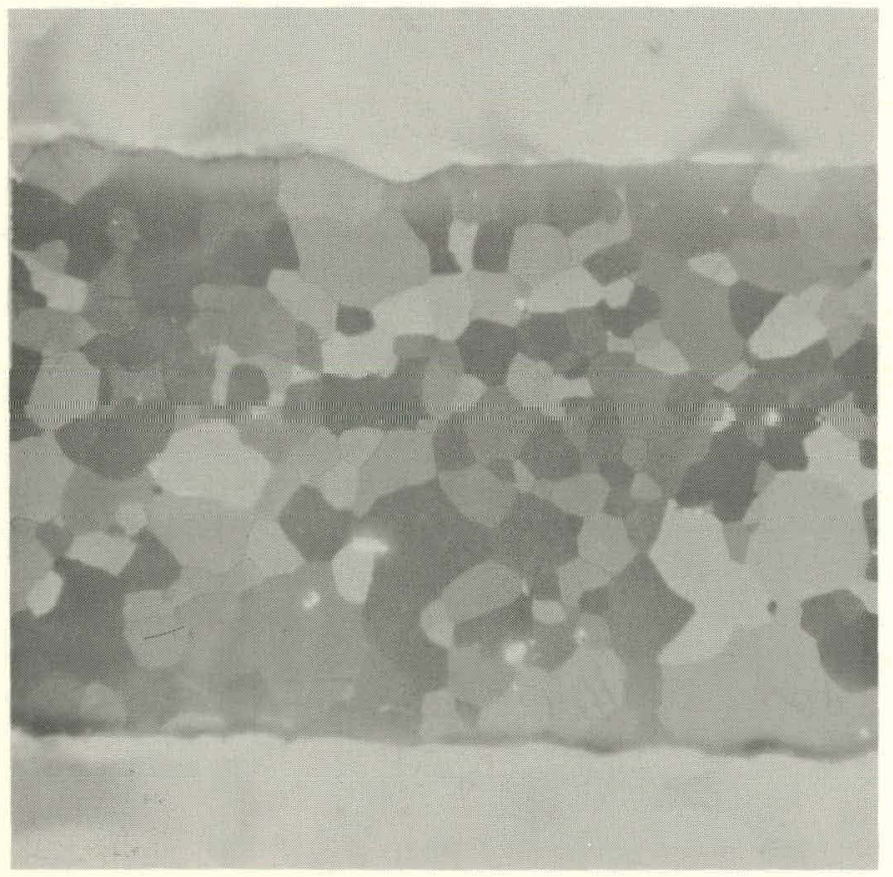

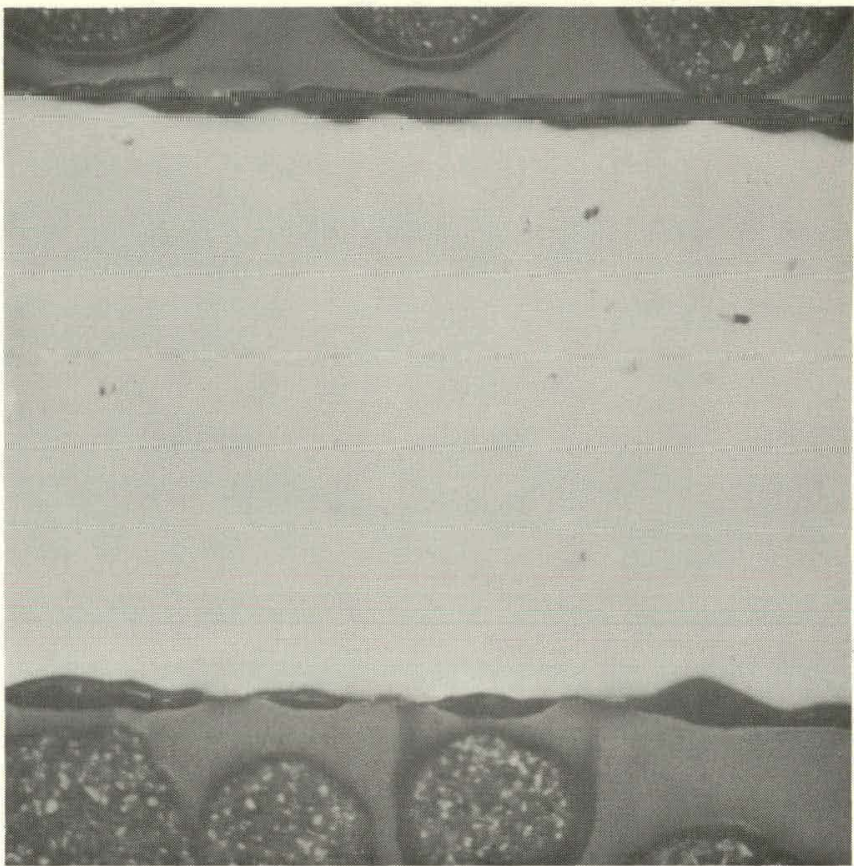

Figure 5. Same Material as Shown in Figures 3 and 4. Longitudinal view 200X. Bright Field.

Figure 7. Starting Sheet Given 13\% Reduction. Note considerable microcracking. Transverse view 200X. Bright Field

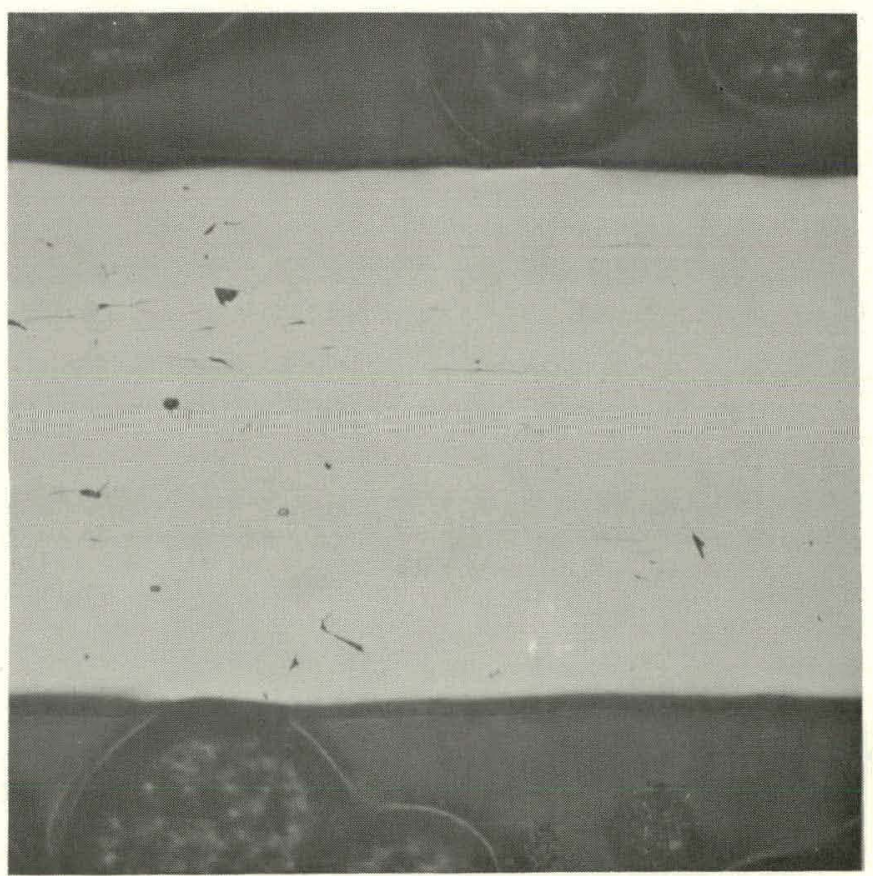




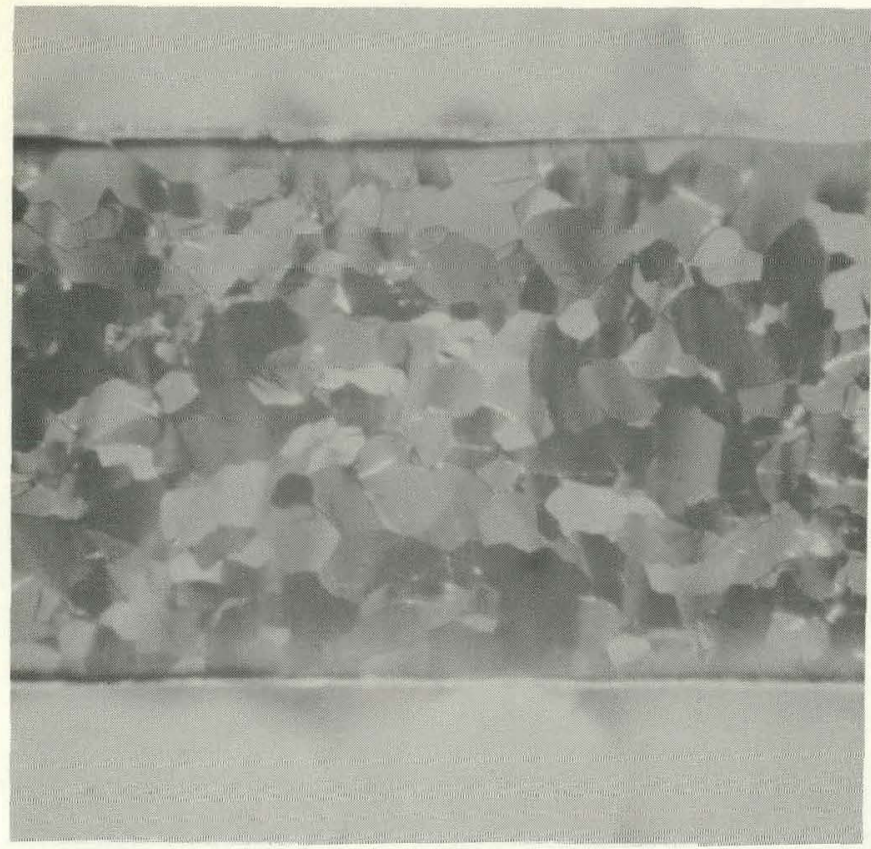

Figure 8. Same Area as Figure 7. Note low angle grain boundaries and lack of any surface damage. Transverse view 200X. Polarized Light.

Figure 10. Same Material as Figures 7 and 8. Longitudinal view 200X. Polarized Light.

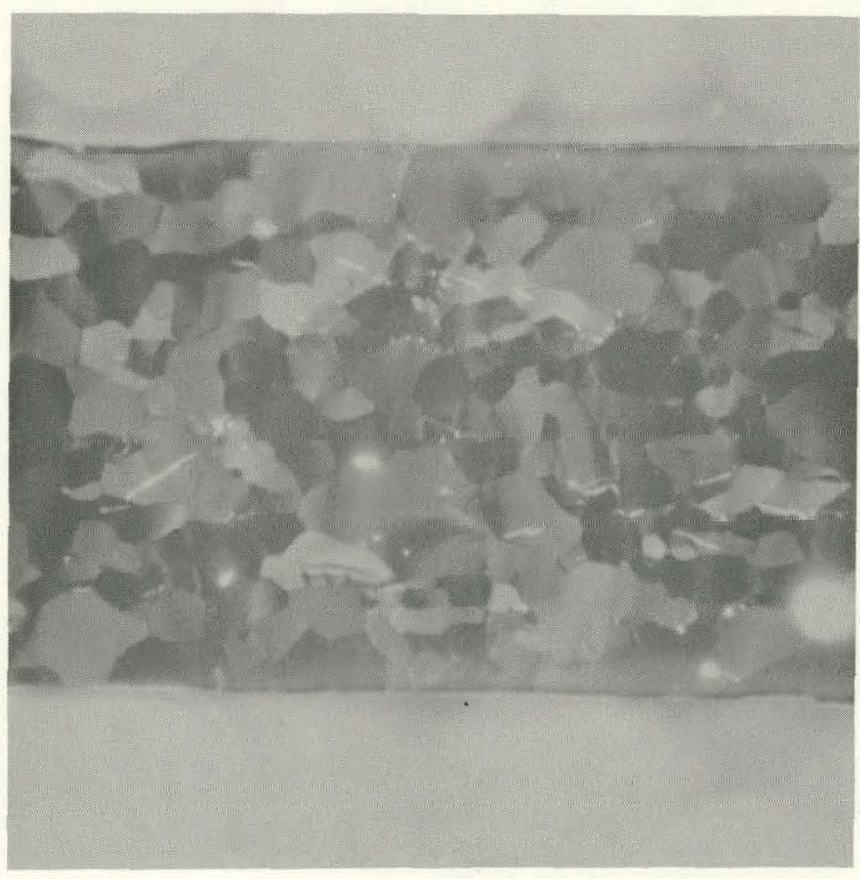

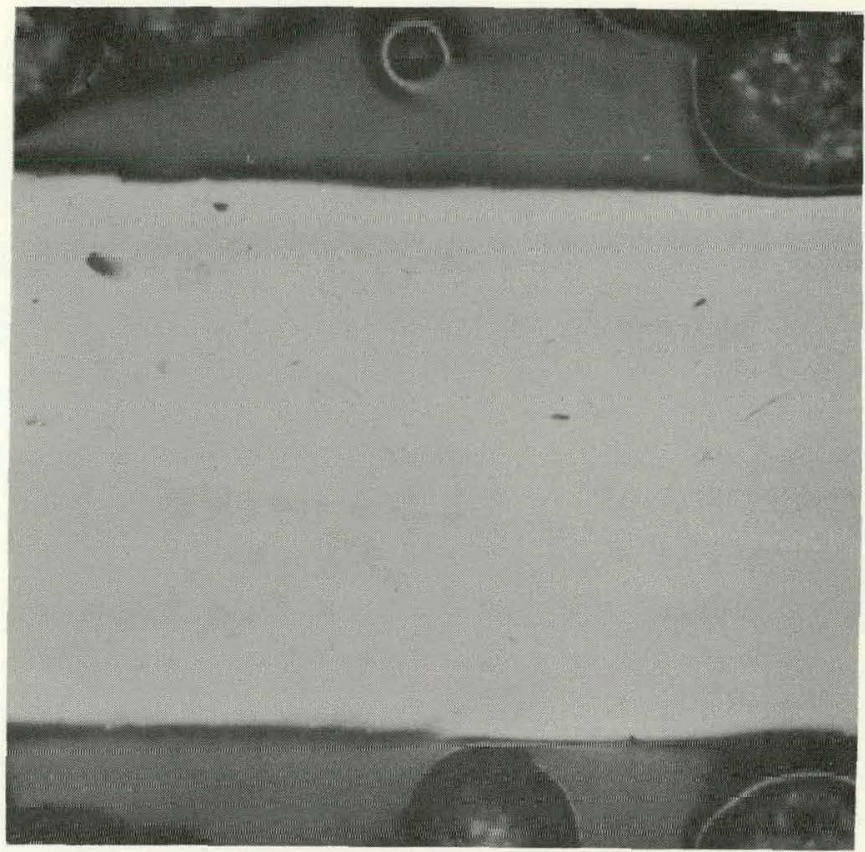

Figure 9. Same Material as Figures 7 and 8. Longitudinal view 200X. Bright Field.

Another characteristic of the foil in Figures 8 and 10 is the smooth, damage-free surface. Some room temperature operations, such as machining, produce heavy surface damage in the form of a type twinning at the edge (Figure 11). This type of damage can be removed by etching off the damaged area. Since room or low temperature rolling does not produce surface damage, no etching to remove surface damage is required.

In summary, it appeared that high surface quality, defectfree foil could be made by rolling provided that the total ductility was not approached since this would cause microcracking; and providing that the oxidation temperature of about $800^{\circ} \mathrm{F}$ was not exceeded.

\section{Annealing}

Initial attempts at annealing high purity beryllium foil in production furnace vacuums $\left(1 \times 10^{-6}\right.$ torr $)$ showed that appreciable oxidation resulting in surface discoloration occurred at any temperature over $1200^{\circ} \mathrm{F}$. To find a method of producing foil which avoided significant oxidation of the surface, studies of annealing response at $1200^{\circ} \mathrm{F}$ for various amounts of cold work were performed. ${ }^{1}$ Figure 11 is a plot of the Knoop hardness versus annealing 


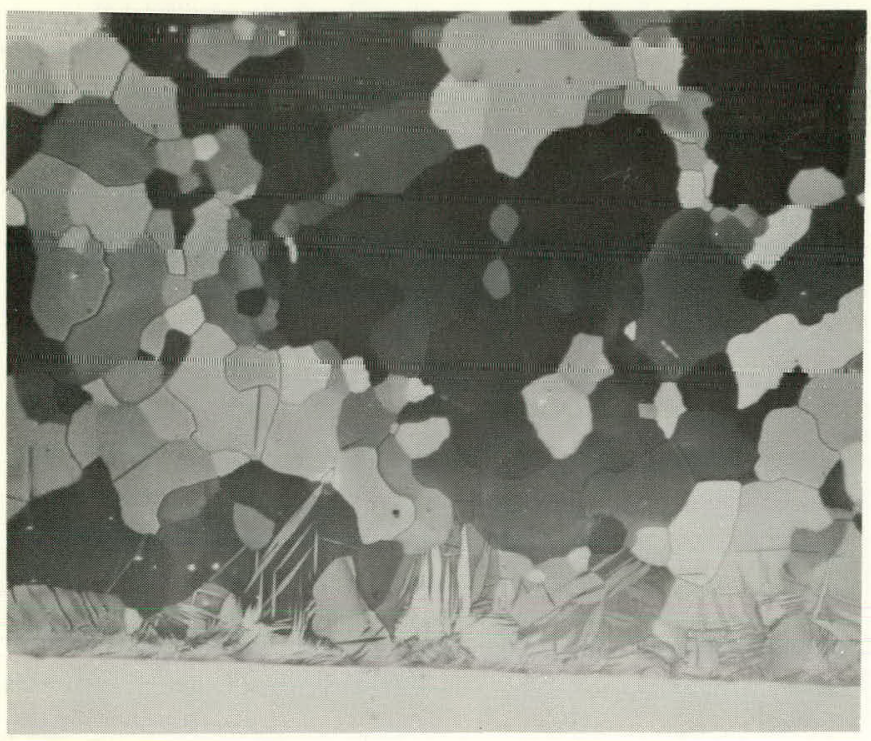

Figure 11. Beryllium Sheet Given a Heavy Cut Machined Surface. Note acicular type twinning damage. Transverse view 200X. Polarized Light.

time at $1200^{\circ} \mathrm{F}$ for foil rolled $11 \%$ and 20 percent. The results show that for 11 and $20 \%$ reduction only partial recovery occurred. Increasing the annealing time at $1200^{\circ} \mathrm{F}$ does not lower the hardness. Based on extrapolation of the data in Figure 12 it appears that 35 to $40 \%$ reduction is necessary in the beryllium before the hardness will approach the fully annealed hardness, if annealing is done at $1200^{\circ} \mathrm{F}$.

Other protective devices were tried in an attempt to increase the annealing temperature above $1200^{\circ} \mathrm{F}$ without oxidizing the foil. The methods and results are shown in Table 2.

In summary, annealing studies showed the following.

a. High surface finish, fully annealed foil could be produced if an etch or chemical could be found which removed the oxide formed during anmeding well above $1300^{\circ} \mathrm{F}$, and which did not pit or roughen the surface.

b. High surface finish foil could be produced by annealing at $1200^{\circ} \mathrm{F}$, thereby avoiding significant oxidation of the surface. However, in order for this foil to be ductile after annealing at $1200^{\circ} \mathrm{F}$ it would have to have been rolled 35 to $40 \%$ reduction in thickness. It was not possible to reduce the the thickness of foil this much, as shown in Figure 1.

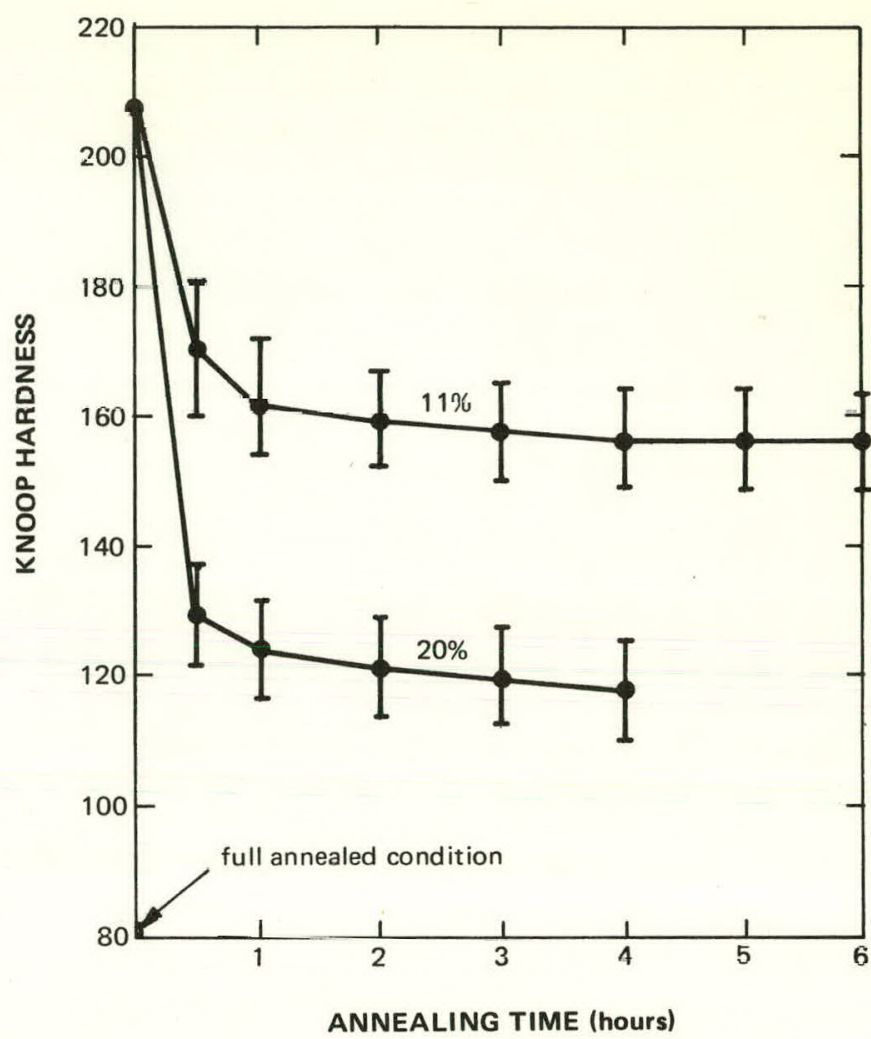

Figure 12. Knoop Hardness versus Annealing Time for Beryllium Foil Rolled 11 and $20 \%$ and Annealed at $1200^{\circ} \mathrm{F}$.

Table 2. Various Protective Systems Tried for Beryllium Anneal to Prevent Oxidation.

\begin{tabular}{|c|c|c|}
\hline System & $\begin{array}{l}\text { Temp } \\
\left({ }^{\circ} \mathbf{F}\right)\end{array}$ & Results \\
\hline $10^{-8}$ torr vacuum & 1400 & Oxidized. \\
\hline High purity argon & 1300 & Formed bluish compound \\
\hline $\begin{array}{l}\text { (Turco-treat) } \\
\text { Cnmmercial coating to } \\
\text { prevent oxidation and } \\
\text { decarburization. }\end{array}$ & 1300 & $\begin{array}{l}\text { Could not be removed } \\
\text { without scraping. }\end{array}$ \\
\hline $\begin{array}{l}10^{-8} \text { torr vacuum with } \\
\mathrm{Ti} \text { "getter" chips }\end{array}$ & 1300 & $\begin{array}{l}\text { The beryllium oxidized } \\
\text { preferentially to the } \\
\text { titaniun. }\end{array}$ \\
\hline
\end{tabular}

\section{Etching}

A progran to find an etching agent which would not roughen the surface was carried out by Chemical Technology Research and Development. Although some improvement over past etching solutions was made, all etches that were tried resulted in roughening of the surface. The basic problem is that any chemical we have tried which will attack the beryllium oxide on the surface of the beryllium 
will also attack beryllium. Since the entire oxide layer is not penetrated simultaneously by the etching solution, and the etchant attacks the beryllium faster than the oxide, surface roughness is inevitable.

\section{FINAL INVESTIGATION}

Based on the initial findings of the work involving rolling, annealing, and etching, the most feasible method of producing high surface finish foil would be by rolling the foil more than $40 \%$ total reduction at temperatures below $800^{\circ} \mathrm{F}$, followed by a $1200^{\circ} \mathrm{F}$ anneal in a $10^{-6}$ torr vacuum.

It had been noticed that foil rolled at temperatures as high as $800^{\circ} \mathrm{F}$ came out of the mill at a temperature which allowed hand handling. The rolls were removing the heat from the foil as it was rolled. It was felt that increased ductility could be realized if this heat transfer were reduced.

Heat transfer calculations were done on the system, as shown below.

The heat loss in the rolls

$$
\Delta h=k_{f} A\left(T_{\text {foil }}-T_{\text {rolls }}\right) d t \int_{t_{1}}^{t_{2}}
$$

where $\mathrm{k}_{\mathrm{f}} \quad=$ heat transfer constant

$$
\begin{aligned}
& \text { A } \quad=\text { area of contact of rolls and foil } \\
& \mathrm{dt} \int_{t_{1}}^{t_{2}}=\begin{array}{c}
\text { time of contact of a given area of } \\
\text { foil with the rolls }
\end{array}
\end{aligned}
$$

For a constant roll speed, $\mathrm{dt} \int_{\mathrm{t}_{1}}^{\mathrm{t}_{2}}$ and $\mathrm{A}$ are approximately
constant.

Then the temperature reduction $\Delta \mathrm{T}$ in the foil $=-\Delta \mathrm{h} / \mathrm{C}_{\mathrm{p}}$ where $C_{p}=$ specific heat of beryllium.

In the temperature range of $\mathrm{RT}$ to $1600^{\circ} \mathrm{F}$ beryllium tensile ductility and reduction of ared are proportional to temperature. Assuming there is also a linear relation between rolling ductility and temperature, and using the slope. given by data points at roll temperatures of RT and $300^{\circ} \mathrm{F}$ (where the increase in rolling ductility was $9 \%$ ) ${ }^{*}$ the extrapolation in Figure 13 is obtained.

*One datum point was obtained with the rolls at $300^{\circ} \mathrm{F}$ (this was dono by torch heating). Intreasing the roll temperature from RT to $300^{\circ} \mathrm{F}$ increases the rolling ductility of the beryllium foil from $20 \%$ to 29 percent.

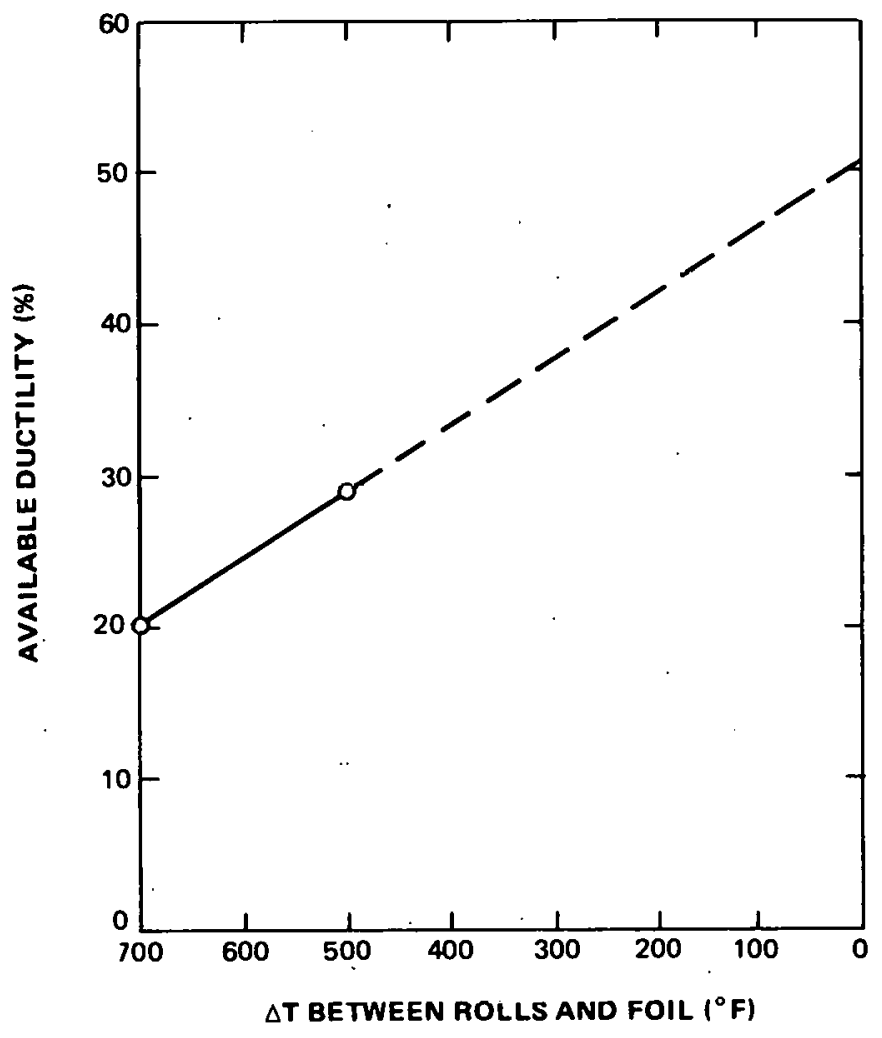

Figure 13. Available Ductility of 0.010-in.-Thick Beryllium Foil Rolled at $800^{\circ} \mathrm{F}$ as a Function of Roll Temperatures from RT to $800^{\circ} \mathrm{F}$.

The extrapolation shows that slightly over $50 \%$ total ductility is available with the rolls and the foil both at $800^{\circ} \mathrm{F}$. This would allow foil to be rolled enough to allow annealing at $1200^{\circ} \mathrm{F}$, with enough rolling ductility left unused to avoid microcracking.

To confirm the calculated data, a heating system utilizing electrical resistance heaters was placed in hollow back up rolls is a 6 in. Stanat Mill as shown in Figure 14. This system was only capable of heating the work rolls to $500^{\circ} \mathrm{F}$. High purity beryllium foil was rolled with the rolls at $500^{\circ} \mathrm{F}$. Figure 15 shows the experimental values of rolling ductility as a function of foil temperature. Also plotted on Figure 15 are the calculated values of ductility to $800^{\circ} \mathrm{F}$. The experimental values are above the calculated ones at roll, at a temperature of $500^{\circ} \mathrm{F}$. This shows that the calculated values of available ductility up to $500^{\circ} \mathrm{F}$ are valid and leads one to expect that the calculated value at $800^{\circ} \mathrm{F}$ is also close to the actual value, if we had becn able to determine it experimentally.

Some experimental work was done to confirm that $40 \%$ reduction would indeed allow recovery of sufficient 


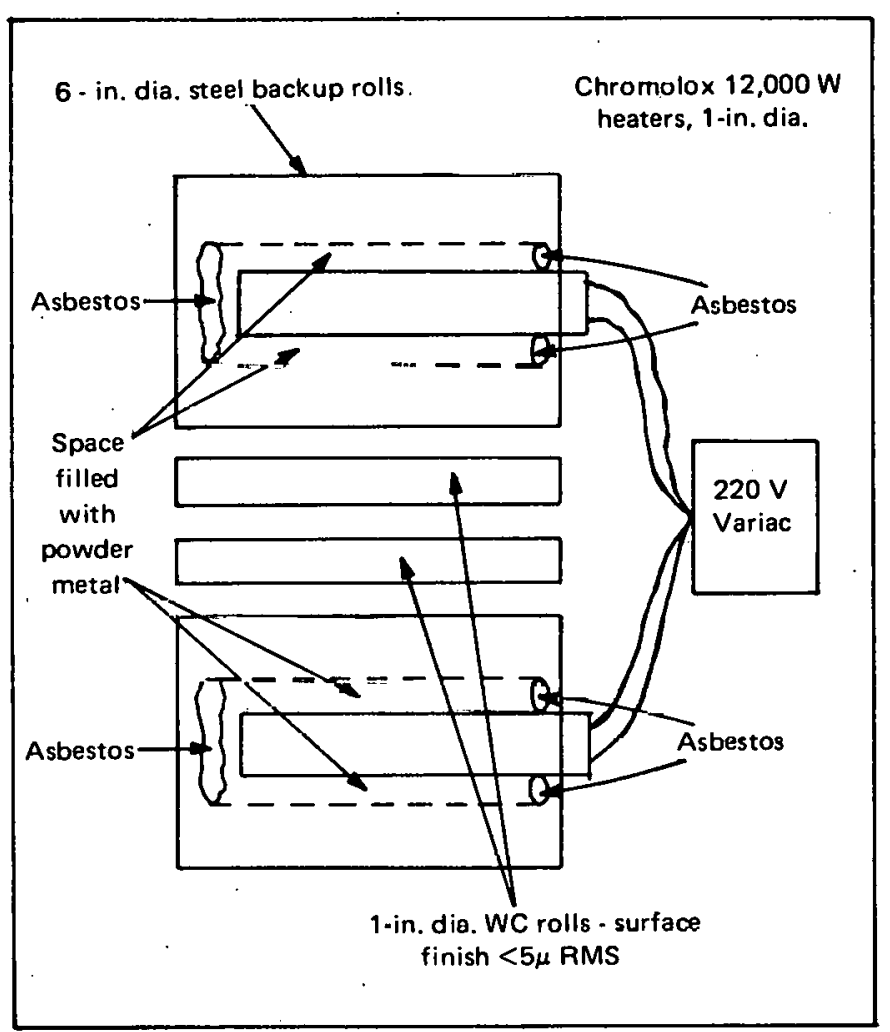

Figure 14. Heated Roll Sotup for Stanat Mill Used in. Hot Roll Experiments.

ductility during a $1200^{\circ} \mathrm{F}$ anneal.** Samples of beryllium foil were. rnlled varinus amountș up to $60 \%$ in llie lieated mill. Several of these samples were polled more than their available ductility and were extensively cracked. For lite purpose of this testing, however, small pieces without cracks would suffice.

All samples were annealed at $1200^{\circ} \mathrm{F}$ for 4 hours. They were then examined visually for surface appearance and were bend tested around a $10 \mathrm{~T}$ bend radius to evaluate ductility. All samples irad a bright, shiny surface appearance. Samples rolled less than $50 \%$ did not possess adequate bend

* When a metal is worked, internal defects are produced which decrease the metal's ductility. When enough defects are produced, the metal has no ductility remaining and it will be brittle. When heat is applied there is a tendency to remove the defects, and restore ductility. The actual degree to which defects are removed is . a funotion of the number nf defects, the temperature at which they were introduced, and the length of time and temperature at which the metal is heated.

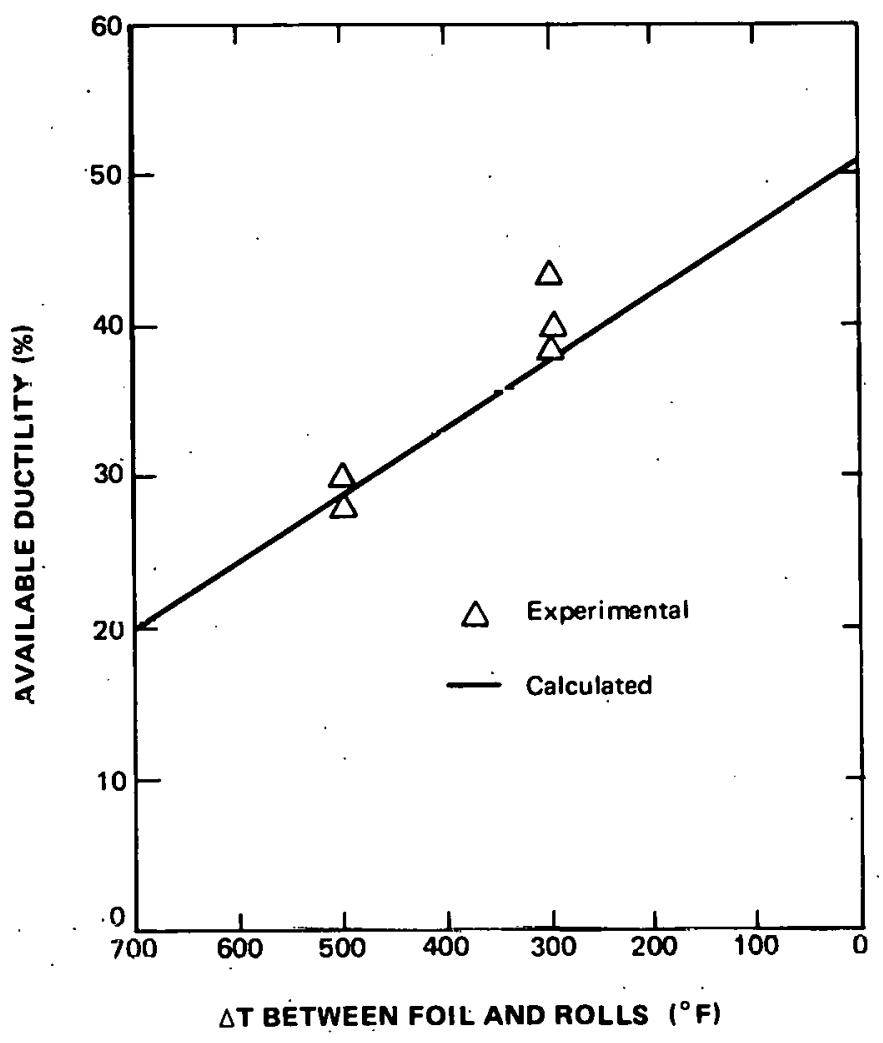

Figure 15. Comparison of Calculated and Experimentally Determined Ductilities of Beryllium Rolled at $800^{\circ} \mathrm{F}$ through Rolls Hosted in the Range from RT to $800^{\circ} \mathrm{F}$,

ductility to survive the bend tests. This amount of reduction is a somowhat higher tigure than the $40 \%$ prevlously sepurted in the initial invostigation. The $40 \%$ figure. was determined by investigation of the hardncss drop during annealing at $1200^{\circ} \mathrm{F}$. It was felt that a partially recrystallized structure (in which the defects are partially removed) would give the foil sufficient ductility, and partial recrystallization is realized with $40 \%$ rcduction foil followed by a $12 n n^{\circ} \mathrm{F}$, 3-hour anneal. The bend tests, being an actual measurc of ductility, showed that metallographic examination is not an accurate way of determining ductility.

\section{REFERENCE}

1. A. W. Brewer, J. G. Avery, and F. J. Fraikor, Recovery in Beryllium Foil, USAEC RFP-1719. 


\section{APPENDIX I}

\section{Present Procedure for Producing Beryllium Foil}

Starting with 0.020 -in. foil, which is in the thickness range obtained after hot rolling of beryllium is completed, smaller diameter and higher surface finish rolls are used to roll down to foil thicknesses.

\section{STAGE I}

\begin{tabular}{cccc} 
Initial & $\begin{array}{c}\text { Final } \\
\text { Thickness }\end{array}$ & $\begin{array}{c}\text { No. of } \\
\text { Thickness }\end{array}$ & $\underline{\begin{array}{c}\text { Surface Finish } \\
\text { After Rolling } \\
(\mu \mathrm{in} / \mathrm{in} \text { rms })\end{array}}$ \\
\hline
\end{tabular}

0.020 in. 0.018 in. $\quad 3 \quad 15$

Anneal at $760^{\circ} \mathrm{C}-6$ hours, trim off cracked edges, etch in $48 \% \mathrm{H}_{2} \mathrm{O}-4 \% \mathrm{HF}-48 \% \mathrm{HNO}_{3}$ solution to remove oxide. Thickness after etching, 0.016 inch. Surface finish after etching, $70 \mu \mathrm{in} / \mathrm{in}$ rms.

\section{STAGE II}

\begin{tabular}{cccc}
$\begin{array}{c}\text { Initial } \\
\text { Thickness }\end{array}$ & $\begin{array}{c}\text { Final } \\
\text { Thickness }\end{array}$ & $\begin{array}{c}\text { No. of } \\
\text { Passes }\end{array}$ & $\begin{array}{c}\text { Surface Finish } \\
\text { After Rolling } \\
(\mu \mathrm{in} / \text { in rms })\end{array}$ \\
\hline 0.016 in. & 0.014 in. & 3 & 15
\end{tabular}

Anneal at $760^{\circ} \mathrm{C}-6$ hours, trim off cracked edges, etch in $48 \% \mathrm{H}_{2} \mathrm{O}-4 \% \mathrm{HF}-48 \% \mathrm{HNO}_{3}$ solution to remove oxide. Thickness after etching, 0.012 inch. Surface finish after etching, $70 \mu \mathrm{in} / \mathrm{in} \mathrm{rms}$.

\section{STAGE III}

\begin{tabular}{|c|c|c|c|}
\hline $\begin{array}{l}\text { Initial } \\
\text { Thickness }\end{array}$ & $\begin{array}{c}\text { Final } \\
\text { Thickness }\end{array}$ & $\begin{array}{l}\text { No. of } \\
\text { Passes }\end{array}$ & $\begin{array}{c}\text { Surface Finish } \\
\text { After Rolling } \\
(\mu \mathrm{in} / \text { in } \mathrm{rms})\end{array}$ \\
\hline 0.012 in. & 0.010 in. & 3 & 15 \\
\hline
\end{tabular}

Anneal at $760^{\circ} \mathrm{C}-6$ hours, trim off cracked edges, etch in $48 \% \mathrm{H}_{2} \mathrm{O}-4 \% \mathrm{HF}-48 \%$. $\mathrm{HNO}_{3}$ solution to remove oxide. Thickness after etching, 0.008 inch. Surface finish, $70 \mu \mathrm{in} / \mathrm{in} \mathrm{rms}$.

\section{STAGE IV}

\begin{tabular}{|c|c|c|c|}
\hline $\begin{array}{c}\text { Initial } \\
\text { Thickness }\end{array}$ & $\begin{array}{l}\text { Final } \\
\text { Thickness }\end{array}$ & $\begin{array}{l}\text { No. of } \\
\text { Passes }\end{array}$ & $\begin{array}{c}\text { Surface Finish } \\
\text { After Rolling } \\
\text { ( } \mu \text { in/in } \mathrm{rms} \text { ) }\end{array}$ \\
\hline $0.008 \mathrm{in}$. & 0.0065 in. & 3 & 15 \\
\hline
\end{tabular}

Anneal at $760^{\circ} \mathrm{C}-6$ hours, trim off cracked edges, etch in $48 \% \mathrm{H}_{2} \mathrm{O}-4 \% \mathrm{HF}-48 \% \mathrm{HNO}_{3}$ solution to remove oxide. Thickness after etching, 0.004 inch. Surface finish after etching, $70 \mu \mathrm{in} / \mathrm{in} \mathrm{rms}$.

\section{STAGE V}

\begin{tabular}{|c|c|c|c|}
\hline $\begin{array}{c}\text { Initial } \\
\text { Thickness }\end{array}$ & $\begin{array}{c}\text { Final } \\
\text { Thickness }\end{array}$ & $\begin{array}{l}\text { No. of } \\
\text { Passes }\end{array}$ & $\begin{array}{l}\text { Surface Finish } \\
\text { Aftcr Rolling } \\
\text { ( } \mu \text { in/in } \mathrm{rms} \text { ) }\end{array}$ \\
\hline 0.004 in. & 0.0035 in. & 3 & 10 \\
\hline
\end{tabular}

Anneal in $10^{-6}$ torr vacuum at $760^{\circ} \mathrm{C}$, trim off cracked edges, etch in phosphoric acid- $\mathrm{H}_{2} \mathrm{O}$ solution to remove light oxide. Thickness after etching, 0.0030 inch. Surface finish $30 \mu \mathrm{in} / \mathrm{in} \mathrm{rms.}\left(750 \mathrm{ml} \mathrm{H}_{3} \mathrm{PO}_{4} 50 \mathrm{ml} \mathrm{H}_{2} \mathrm{SO}_{4}, 50 \mathrm{~g}\right.$ $\mathrm{CrO}_{3}$ with $2000 \mathrm{ml}$ distilled $\mathrm{H}_{2}$ O.)

\section{STAGE VI}

\begin{tabular}{|c|c|c|c|}
\hline $\begin{array}{l}\text { Initial } \\
\text { Thickniess }\end{array}$ & $\begin{array}{c}\text { Final } \\
\text { Thickness }\end{array}$ & $\begin{array}{l}\text { No. of } \\
\text { Passes }\end{array}$ & $\begin{array}{c}\text { Surface Finish } \\
\text { After Rolling } \\
\text { ( } \mu \text { in/in } \mathrm{rms})\end{array}$ \\
\hline .003 & 0.0027 in. & 3 & 10 \\
\hline
\end{tabular}

Repeat annealing, etching, and trimming procedures of Stage V. Thickness after etching, 0.0025 inch. Surface finish after etching $30 \mu \mathrm{in} / \mathrm{in} \mathrm{rms}$.

\section{SI'AGE VII}

$\begin{array}{cccc}\begin{array}{c}\text { Initial } \\ \text { Thickness }\end{array} & \begin{array}{c}\text { Final } \\ \text { Thickness }\end{array} & \begin{array}{c}\text { No. of } \\ \text { Passes }\end{array} & \begin{array}{c}\text { Surface Finish } \\ \text { After Rolling: } \\ (\mu \mathrm{in} / \text { in rms })\end{array} \\ 0.0025 \mathrm{in} . & 0.0021 \mathrm{in} . & 3 & 10\end{array}$

Final annealing, trimming, and chemical cleaning produce a 0.0020 -in.-thick beryllium foil having a surface finish of 20 to $30 \mu \mathrm{in} / \mathrm{in} \mathrm{rms}$. 